\title{
Quali-quantitative characterization of organic matter in urbanized drainage basins as a basis for the application of Water Resources Management Instruments
}

\section{Caracterização quali-quantitativa da Matéria Orgânica em bacias hidrográficas urbanizadas como base para a aplicação dos Instrumentos de Gestão de Recursos Hídricos}

\author{
Juliana Leithold ${ }^{1}$, Cristóvão Vicente Scapulatempo Fernandes ${ }^{1}$, Heloise Garcia Knapik $^{1}$ and \\ Júlio César Rodrigues de Azevedo ${ }^{2}$
}

${ }^{1}$ Universidade Federal do Paraná, Curitiba, PR, Brazil

${ }^{2}$ Universidade Tecnológica Federal do Paraná, Curitiba, PR, Brazil

E-mails: juleithold@gmail.com (JL), cris.dhs@ufpr.br (CVSF), heloise.dhs@ufpr.br (HGK), jcrazevedo.utfpr@gmail.com (JCRA)

Received: December 20, 2016 - Revised: June 05, 2017 - Accepted: July 29, 2017

\begin{abstract}
The challenge imposed by law no. 9433/97 to establish mechanisms for the recovery of bodies of water led to a dynamic of research that could guarantee not only an adequate understanding of the management instruments but also the technical basis for their application. In this research, emphasis was placed on understanding the dynamics of organic matter (OM) in a drainage basin heavily influenced by anthropogenic activities, through the analysis and interpretation of qualitative and quantitative information. The case study was the Iguaçu River basin, from its headwaters in the Metropolitan Region of Curitiba (MRC) to the municipality of União da Vitória The results obtained showed a large deposition of labile OM in the MRC coming probably from domestic effluents, with consequent DO depletion and water quality degradation. However, after the more urbanized region, there is a reduction in the concentration of $\mathrm{OM}$ and the indication of the predominance of pedogenic material, suggesting that in addition to the dilution effect, there is less input of anthropogenic effluents in this region, which results in an improvement in water quality, represented mainly by the recovery of the DO concentration. The combined use of quantitative data and UV-visible spectroscopy was fundamental to comprehend the variation in the characteristics of $\mathrm{OM}$ and its sources along the studied section.
\end{abstract}

Keywords: Water quality; UV-Visible; Urban basins; Iguaçu River.

\section{RESUMO}

O desafio imposto pela lei n. 9433/97 de estabelecer mecanismos de recuperação de corpos hídricos induziu a uma dinâmica de pesquisas que pudessem garantir, não só o adequado entendimento dos instrumentos de gestão, mas a fundamentação técnica necessária à sua aplicação. Nesta pesquisa, ênfase foi dada na compreensão da dinâmica da MO em bacia hidrográfica fortemente influenciada pelas atividades antrópicas, através da análise e interpretação conjunta de informações qualitativas e quantitativas. O estudo de caso abordado foi a bacia do rio Rio Iguaçu e os resultados obtidos demonstraram grande aporte de MO lábil na RMC proveniente provavelmente de efluentes domésticos, com consequente depleção do OD e degradação da qualidade das águas. No entanto, após a região mais urbanizada há redução da concentração de $\mathrm{MO}$ e a indicação da predominância de material pedogênico, sugerindo que além do efeito de diluição, há menor aporte de efluentes antrópicos nesta região, o que resulta numa melhoria da qualidade das águas, representada principalmente pela recuperação da concentração do OD. A utilização conjunta dos dados quantitativos e da espectroscopia de UV-visível foi fundamental para compreender a variação nas características da MO e de suas fontes ao longo do trecho estudado.

Palavras-Chave: Qualidade da água; Uv-Visível; Bacias urbanas; Rio Iguaçu. 
Quali-quantitative characterization of organic matter in urbanized drainage basins as a basis for the application of Water Resources Management Instruments

\section{INTRODUCTION}

The availability of water in conditions of quali-quantitative equilibrium and appropriate to its multiple uses is fundamental to the maintenance of natural processes and the biome, as well as human health and activities. Water resources are directly and indirectly affected by the type of occupation and land use in the river basins, due to their level of impermeabilization, existing plant cover, types of residues and effluents generated by the developed activities, dynamics of the matrix of pollution sources, mechanisms of diffuse pollution, among others (SEMA, 2013).

In this context, the implementation of water resources management instruments in drainage basins with strong pressure for urbanization is still a challenge given the magnitude of the degradation of their bodies of water and the difficulties in understanding the effects of the combination of physical, chemical and biological aspects on its nature, as in the case of many metropolitan regions. In this research, the objective is the characterization of aquatic organic matter $(\mathrm{OM})$ in the Upper Iguaçu basin in the Metropolitan Region of Curitiba (MRC), following the conceptual and applied evolution through several studies such as Lopardo, Fernandes and Azevedo (2008), Santos et al. (2011), Bem et al. (2013) and Knapik, Fernandes and Azevedo (2014).

When the reference focus is the establishment of chemical or biological qualitative characteristics, it is focused, in general, on the dynamics of the aquatic organic matter. Its nature is of crucial importance to life as it is the basis of the food chain, acts on the transport and availability of nutrients, interferes with the penetration of sunlight into the bodies of water and may alter the toxicity of certain substances (FRIMMEL, 1998; CHEN et al., 2002). However, if present in excess, it can lead to degradation of water resources.

Organic matter reflects a mixture of several compounds with the most varied sizes and chemical and structural compositions, produced by the decomposition of animal and vegetable residues and byproducts, and their characteristics are primarily dependent on their origin and age (AIKEN; COTSARIS, 1995; CHEN et al., 2002). When originated inside the aquatic system, it is called autochthonous, or aquagenic, and when coming from sources external to the aquatic system, it is called allochthonous, varying from natural, pedogenic or produced by human activities, thus denominated allochthonous anthropogenic (ZUMSTEIN; BUFFLE, 1989; AIKEN; COTSARIS, 1995; FILELLA, 2009).

Regarding their composition, organic matter can be divided into more labile and well-defined substances, such as proteins, peptides and amino acids, and humic substances, which have more complex structures. It can also be separated into three classes according to their solubility at different $\mathrm{pH}$ ranges: humin, insoluble at any $\mathrm{pH}$, humic acids, insoluble at $\mathrm{pH}$ below 2, and fulvic acids, soluble at all $\mathrm{pH}$ ranges (ESTEVES, 1998; CHEN et al., 2002). The labile compounds are of easy degradation, taking days or weeks to decompose, while humic substances are highly refractory, taking hundreds or even thousands of years to be degraded (ZUMSTEIN; BUFFLE, 1989).

The aquagenic organic matter is composed of labile and refractory molecules, generally with aliphatic structures (RAOM). Being the refractory pedogenic organic matter (RPOM) derived from decomposed substances within the soil, it has a molecular structure with larger amounts of aromatic structures, such as, for example, fulvic acids (ZUMSTEIN; BUFFLE, 1989; WILKINSON; JOZ-ROLAND; BUFFLE, 1997). The allochthonous anthropogenic organic matter consists mainly of biodegradable substances such as lipids, carbohydrates and surfactants, but may also contain refractory compounds (POUET et al., 2007).

Due to its complexity, the characterization of the organic matter is a great challenge (CHEN et al., 2002). It is constituted of different compounds with great variation in their properties and forms of analysis, being the results dependable both on the sample's origin and method of preparation. However, despite all these difficulties, the quantification of organic matter in a body of water is often necessary for water resources management and the definition of public policies of decontamination (FILELLA, 2009).

Therefore, several analytical techniques can be employed on the characterization of organic matter, considering that such choice will depend on the purpose of the utilization of the data (KNAPIK, 2014). Regarding the quantitative methods, we have: Biochemical Oxygen Demand (BOD), Chemical Oxygen Demand (COD) and Total, Particulate and Dissolved Organic Carbon (TOC, POC and COD, respectively).

The BOD is an indirect measure of the organic matter present in a sample because it quantifies the oxygen consumed in its degradation by the action of bacteria and other micro-organisms (KUMAR; KUMAR, 2005; JOUANNEAU et al., 2014). It is also one of the most used parameters for water quality assessment (JOUANNEAU et al., 2014). Nonetheless, it relies heavily in the bacterial community, which causes great variation in its results (COMBER et al., 1996; APHA, 1999).

In cases where the presence of microorganisms is sparse or there are substances or conditions limiting their growth, the results of the BOD may be underestimated. In addition, the BOD requires a long time for the acquisition of results, 5 days, hindering the implementation of emergency actions. Furthermore, the presence of bubbles, iron ions or sulfides in the analysis flasks, as well as inhomogeneous samples, may interfere with the obtained results (COMBER et al., 1996; APHA, 1999; KUMAR; KUMAR, 2005; JOUANNEAU et al., 2014).

The COD, similar to the BOD, is an indirect measuring of the organic matter represented by the oxygen consumed in its chemical oxidation. However, some organic compounds such as aliphatic and aromatic halogenated hydrocarbon are not completely degraded in the COD test (HU; GRASSO, 2005). Moreover, the presence of inorganic substances can alter its results and the residues generated in this type of analysis are considered dangerous due to the presence of hexavalent chromium and mercury salts (APHA, 1999).

The TOC, which is a direct measure of the carbon atoms present in a sample, is calculated by quantifying the carbon dioxide $\left(\mathrm{CO}_{2}\right)$ released in the breakdown of the organic matter, either due to high temperatures, the presence of oxidants along with the action of heat, or even due to ultraviolet radiation. The TOC can be divided into POC, which is the fraction retained in a membrane (namely, a $0.45 \mu \mathrm{m}$ one), while the DOC is the fraction that passes through that membrane (APHA, 1999). DOC can be obtained in the same way as the TOC, however through the analysis of the filtered sample, and the POC is obtained by the difference 
between the two other fractions or through the determination of the material retained in the membrane (KNAPIK, 2014).

The main interference in this essay is the incomplete elimination of the inorganic carbon from the sample, which may in turn be quantified as organic carbon, altering the results. Other sources of error in the analysis include: the presence of gaseous residues such as water vapor or nitrogen compounds, which interfere with the detection of the $\mathrm{CO}_{2}$ produced during the combustion method; the turbidity of the samples, which attenuates the effect of UV radiation, reducing the oxidation of $\mathrm{OM}$; and the type of membrane used in the DOC analysis, which may cause over or underestimation of the values (APHA, 1999; VISCO et al., 2005).

In Brazil, the BOD is the only indicator of organic matter concentration issued in the Resolution 357/2005 of the Brazilian Environment National Council (CONAMA). This resolution establishes the framework for water bodies classification (CONAMA, 2005). Generally, the higher the BOD, the lower the dissolved oxygen (DO), due to its consumption by the aerobic microorganisms during the decomposition of the biodegradable organic matter, causing the deterioration of the quality of the water resources.

The use of quantitative methods is important in assessing the degree of pollution of a watercourse. However, they do not provide information on molecular structure or sources of organic matter. In this sense, qualitative methods, such as UV-visible spectroscopy, act as indicative of the aromatic content of organic matter and, consequently, point to their probable sources within the aquatic ecosystem (WESTERHOFF; ANNING, 2000; LEENHEER; CROUÉ, 2003).

Spectroscopic methods are based on the interaction between matter and radiation, being classified according to the spectral range being used. Absorption spectroscopy within the UV-visible evaluates the amount of light absorbed by a given sample when irradiated with energy in the region of Ultraviolet and Visible (180 to $780 \mathrm{~nm}$ ) (SKOOG et al., 2006).

According to Beer-Lambert's Law, the absorbance of a sample is directly proportional to the molar absorptivity, which is characteristic of each compound, being dependent on the arrangement and number of electrons in each molecule; on the concentration of the compound; and on the optical path that light crosses (VINADÉ; VINADÉ, 2005; SKOOG et al., 2006; PAVIA et al., 2012). Thus, the shape of the absorption spectrum is characteristic of the type and concentration of the compounds present in a sample, making its application possible both in the quantitative and qualitative characterization of samples (VINADÉ; VINADÉ, 2005).

Compounds containing carbon-carbon double bonds absorb a greater amount of visible light in the 250 to $280 \mathrm{~nm}$ range. Thus, the higher the aromatic content, the higher the absorbance. Finally, indexes such as the specific ultraviolet absorbance in $254 \mathrm{~nm}\left(\mathrm{SUVA}_{254}\right.$ in $\left.\mathrm{L}(\mathrm{mg} \mathrm{m})^{-1}\right)$ - obtained through the ratio between the absorbance at $254 \mathrm{~nm}$ and the DOC $\left(\mathrm{mg} \mathrm{L}^{-1}\right)$, and normalized by the optical path in the cuvette $(\mathrm{m})$ - indicate the probable predominant source of organic matter in the sample. Values of $\mathrm{SUVA}_{254}$ on the order of $4.4 \mathrm{~L}(\mathrm{mg} \mathrm{m})^{-1}$ indicate the predominance of pedogenic organic matter, while lower values close to $1.2 \mathrm{~L} \mathrm{(mg} \mathrm{m})^{-1}$ are evidence of an organic matter of simpler structure, characteristic of aquagenic sources or domestic effluents (WESTERHOFF; ANNING, 2000).

Another parameter is the ratio between the absorbance at $285 \mathrm{~nm}$ and the DOC $\left(\mathrm{A}_{285} / \mathrm{DOC}\right.$ in $\left.\mathrm{L} \mathrm{g}^{-1}\right)$. Values lower than or close to $10 \mathrm{~L} \mathrm{~g}^{-1}$, suggest the presence of aliphatic compounds from primary production, i.e. aquagenic source. However, values close to $20 \mathrm{~L} \mathrm{~g}^{-1}$ would be associated to the presence of organic pedogenic matter, composed mainly of fulvic acids, whose molecular structure is basically aromatic (ROSTAN; CELLOT, 1995). Low values of $\mathrm{A}_{285}$ /DOC can also indicate the presence of labile compounds present in domestic effluents (BEM et al., 2013).

The quantitative methods, mainly the BOD and COD, are used as indicators of the State of balance or degradation of water resources. However, many researchers have used optical methods, such as fluorescence spectroscopy and ultraviolet-visible absorption, which were also used in the qualitative characterization of organic matter in water bodies such as lakes and reservoirs (NGUYEN; HUR, 2011; HESTIR et al., 2015), regions with strong presence of urbanization (HUR; KONG, 2008; LOPARDO; FERNANDES; AZEVEDO, 2008; SANTOS et al., 2011; BEM et al., 2013; MENG et al., 2013; DONG et al., 2014; KNAPIK; FERNANDES; AZEVEDO, 2014; YU et al., 2015) and oceanic regions (DANG et al., 2014; YAMASHITA et al., 2015). Additionally, researchers have performed comparisons between water bodies' characteristics in different aquatic (WEISHAAR et al., 2003) environments. Thus, demonstrating the wide application of all methods previously listed in scientific research.

Weishaar et al. (2003) analyzed the efficiency in the use of $\mathrm{SUVA}_{254}$ in determination of chemical reactivity and aromaticity level of aquatic OM from different sources. The results of the study suggested strong correlation between $\mathrm{SUVA}_{254}$ and the aromatic carbon content, but low between the reactivity of DOC in front of various reagents.

Lopardo, Fernandes and Azevedo (2008) assessed the $\mathrm{OM}$ in Barigüi's River and Lake through analysis of UV-visible spectroscopy and fluorescence, along with COD, BOD, DOC and TOC during 5 monitoring campaigns. The results indicated that the OM present in the Lake presented more labile, thus, it is not possible to determine whether the source was autochthonous or allochthonous anthropogenic due to the absence of other parameters, such as the analysis of chlorophyll-a or thermotolerant coliforms. SUVA $_{254}$ values varied from 0.8704 the $1.6470 \mathrm{~L}(\mathrm{mg} \mathrm{m}){ }^{-1}$ in

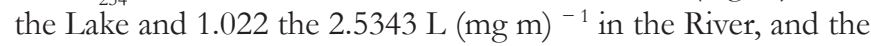
$\mathrm{A}_{285} / \mathrm{DOC}$ they varied from 5.98 to $11.55 \mathrm{~L} \mathrm{~g}^{-1}$ in the Lake and from 7.17 to $16.86 \mathrm{~L} \mathrm{~g}^{-1}$ in the river. As for the BOD values there was a variation from 3.0 to $19.60 \mathrm{mgO}_{2} \mathrm{~L}^{-1}$ in the Lake and from 1.00 to $21.63 \mathrm{mgO}_{2} \mathrm{~L}^{-1}$ in the river.

Nguyen and Hur (2011) used several analytical techniques of OM characterization, among them the $\mathrm{SUVA}_{254}$ along with the principal component analysis (PCA), in order to evaluate chemical and structural characteristics of refractory organic matter dissolved from different sources and suggest their main sources. The values of $\mathrm{SUVA}_{254}$ had great variation from 1.51 to $\left.5.26 \mathrm{~L} \mathrm{(mg} \mathrm{m)}\right)^{-1}$, in which low values indicated that $\mathrm{OM}$ refractory fractions may contain non-aromatic compounds.

Santos et al. (2011) characterized OM in the basin of Upper Iguaçu by collection at its main river, Palmital River and Atuba River, tributaries from the right bank of the Iguaçu River, Pequeno River, a tributary from the left bank and a dig near the 
Iguaçu River through fluorescence spectroscopy. Regarding the Excitation-Emission Matrices (EEMs) and the comparison between the results obtained for the points studied, the authors assessed the fractions of OM prevalent, suggesting that the rivers analyzed had contamination by domestic effluent.

Bem et al. (2013) used spectroscopic techniques (fluorescence and UV-visible) to evaluate and compare the $\mathrm{OM}$ in monitoring points of Iguaçu River and the Barigüi Lake. Based on the results of SUVA 254 (average varying from 0.85 to $2.01 \mathrm{~L}(\mathrm{mg} \mathrm{m})^{-1}$ ) and $\mathrm{A}_{285} / \mathrm{DOC}$ (average varying from 6.04 to $13.94 \mathrm{~L} \mathrm{~g}^{-1}$ ) was verified that the $\mathrm{OM}$ in the points studied showed predominance of labile fraction. The points located in Iguaçu River were probably contaminated by domestic sewage, due to their lotic characteristic and therefore exposing low presence of algae.

Dong et al. (2014) investigated the characteristics and the seasonal variation of the aquatic $\mathrm{OM}$ of a river located in a very urbanized region in China, through the results of DOC and the fluorescence spectroscopy and UV-visible, with the assistance of statistical tools. The values of $\mathrm{SUVA}_{254}$ were on average higher than in autumn $\left(9.18 \mathrm{~L}(\mathrm{mg} \mathrm{m})^{-1}\right)$ and lower than in the spring $\left(5.02 \mathrm{~L}(\mathrm{mg} \mathrm{m})^{-1}\right)$, indicating that $\mathrm{OM}$ has a variable source throughout the seasons.

In another study, Knapik, Fernandes and Azevedo (2014) used the same spectroscopic techniques, in addition to the quantification of $\mathrm{OM}$ for $\mathrm{BOD}, \mathrm{COD}$ and $\mathrm{DOC}$, to analyze the water quality on the Iguaçu River, complementing the study by Bem et al. (2013). The average of values obtained for BOD varied from the point less polluted upstream of the MRC between 3.3 to $18 \mathrm{mgO}_{2} \mathrm{~L}^{-1}$ in the most urbanized region. COD (average varying from 18.2 to $43.8 \mathrm{mgO}_{2} \mathrm{~L}^{-1}$ ) and DOC (from 6.0 to $7.7 \mathrm{mgC} \mathrm{L}^{-1}$ ) also presented variance between these regions. Regarding the results of $\mathrm{SUVA}_{254}\left(2.1\right.$ to $\left.2.4 \mathrm{~L}(\mathrm{mg} \mathrm{m})^{-1}\right)$ and $\mathrm{A}_{285} / \mathrm{DOC}\left(14.7\right.$ to $\left.16.7 \mathrm{~L} \mathrm{~g}^{-1}\right)$, there was no indication of a mix between fractions of labile and refractory OM, i.e. to both autochthonous and allochthonous $\mathrm{OM}$ resources.

In this context, the present study had as objective to: a) characterize organic matter present in the Iguaçu River quali-quantitatively evaluating the pressure exerted by the urbanization of the MRC on its waters, extending the analysis undertaken by works such as those of Bem et al. (2013) and Knapik, Fernandes and Azevedo (2014) by the inclusion of 3 monitoring points in the municipalities of Porto Amazonas, São Mateus do Sul and União da Vitória; b) investigate the possible recovery of water quality on the Iguaçu River downstream of the MRC, in areas with lower impact of urbanization; c) use in an integrated manner the DO, BOD, COD, DOC data, and the SUVA ${ }_{254}$ and $\mathrm{A}_{285} /$ DOC indices in order to understand the sources of pollution and changes in the predominance of organic matter along the route studied the river.

\section{MATERIALS AND METHODS}

\section{Area of study}

The Iguaçu River basin is located in the South of the State of Paraná, in southern Brazil, covering part of the State of Santa Catarina and Argentina. This basin has a total area of $65,893 \mathrm{~km}^{2}$, being $54,820 \mathrm{~km}^{2}$ in the territory of Paraná (SEMA, 2013; ANA, 2015). The portion of Paraná was divided into three Basins, according to the resolution 49/2006 of the
State Council of Water Resources of Paraná (CERH-PR), as Upper, Middle and Lower Iguaçu (CERH-PR, 2007).

The basin of Upper Iguaçu, on the other hand, with an area of $12,387 \mathrm{~km}^{2}$, encompasses the Metropolitan Region of Curitiba (MRC) and has a population density of 252.3 (inhabitants per $\mathrm{km}^{2}$ ), being $92 \%$ of its population residing in urban areas. The basin is responsible for $43 \%$ of the State GNP (IPARDES, 2013), besides being the most industrialized of Paraná (SEMA, 2013). Approximately $75 \%$ of the households are serviced by sewage collection network. However, due to excessive urban occupation, the region exerts strong pressure on water resources by altering the quality of their waters (IPARDES, 2013).

On the other hand, the basin of Middle Iguaçu has low demographic density, approximately 23.6 (inhabitants per $\mathrm{km}^{2}$ ) in an area of $17,073 \mathrm{~km}^{2}$ with a degree of urbanization of $73 \%$. Despite the low occupation of the area, the lack of infrastructure is recurrent in this portion of the basin, with the highest percentage of poor families in the State, $12.6 \%$, where only $41.8 \%$ of the households are assisted by the sewage network collection (IPARDES, 2013).

Thus, aiming at the assessment of the high urbanization interference in the quali-quantitative characteristics of aquatic organic matter, samples were collected from 2014 until 2016 in ten points of the Iguaçu River, starting at MRC until the municipality of União da Vitória, along a stretch of approximately $385 \mathrm{~km}$. Such collections covered nine locations of the Upper Iguaçu basin and a control point at Middle Iguaçu basin, located in a less urbanized region. The collection points of the area studied, as well as the soil use and occupation, are highlighted in Figure 1.

The points IG2 to IG4 are located in the region of greater urban concentration of the Upper Iguaçu basin, while the remaining points are located in regions with greater predominance of agriculture and natural or altered vegetation. The point IG2 is located just after the formation of the Iguaçu River, at the confluence of Atuba and Iraí rivers, and at this point the samples were collected on the right margin (IG2D), with greater influence of Atuba River, and on the left margin (IG2E), with greater influence of Iraí River. Some characteristics of the points analyzed are described in Table 1.

Four campaigns were conducted for the data to be obtained, in March and July of 2014 and March and June of 2016.

\section{METHODS}

To evaluate the aquatic organic matter in the Iguaçu River, the analyses of DO, BOD, COD, DOC and UV-Visible spectroscopy were performed. The DO was measured in field by the use of multiparameter probes of the brands $\mathrm{Hach}^{\circledR}$ and Horiba ${ }^{\circledR}$. The $\mathrm{BOD}_{5}$ was obtained in two ways, as described in the method $5210 \mathrm{~B}$ of the 20th Edition of the Standard Methods for Examination of Water and Wastewater, of 1999: the initial and final DO were determined by the method 4500-O C, Winkler modified with sodium azide (APHA, 1999), and by the Respirometric method, using the WTW OxiTop ${ }^{\circledR}$ equipment (JOUANNEAU et al., 2014).

The COD was determined by the method 5220D, colorimetric closed reflux (APHA, 1999). The DOC was measured in samples filtered on cellulose acetate membrane with porosity of $0.45 \mu \mathrm{m}$, by the application of the High-Temperature Combustion Method 


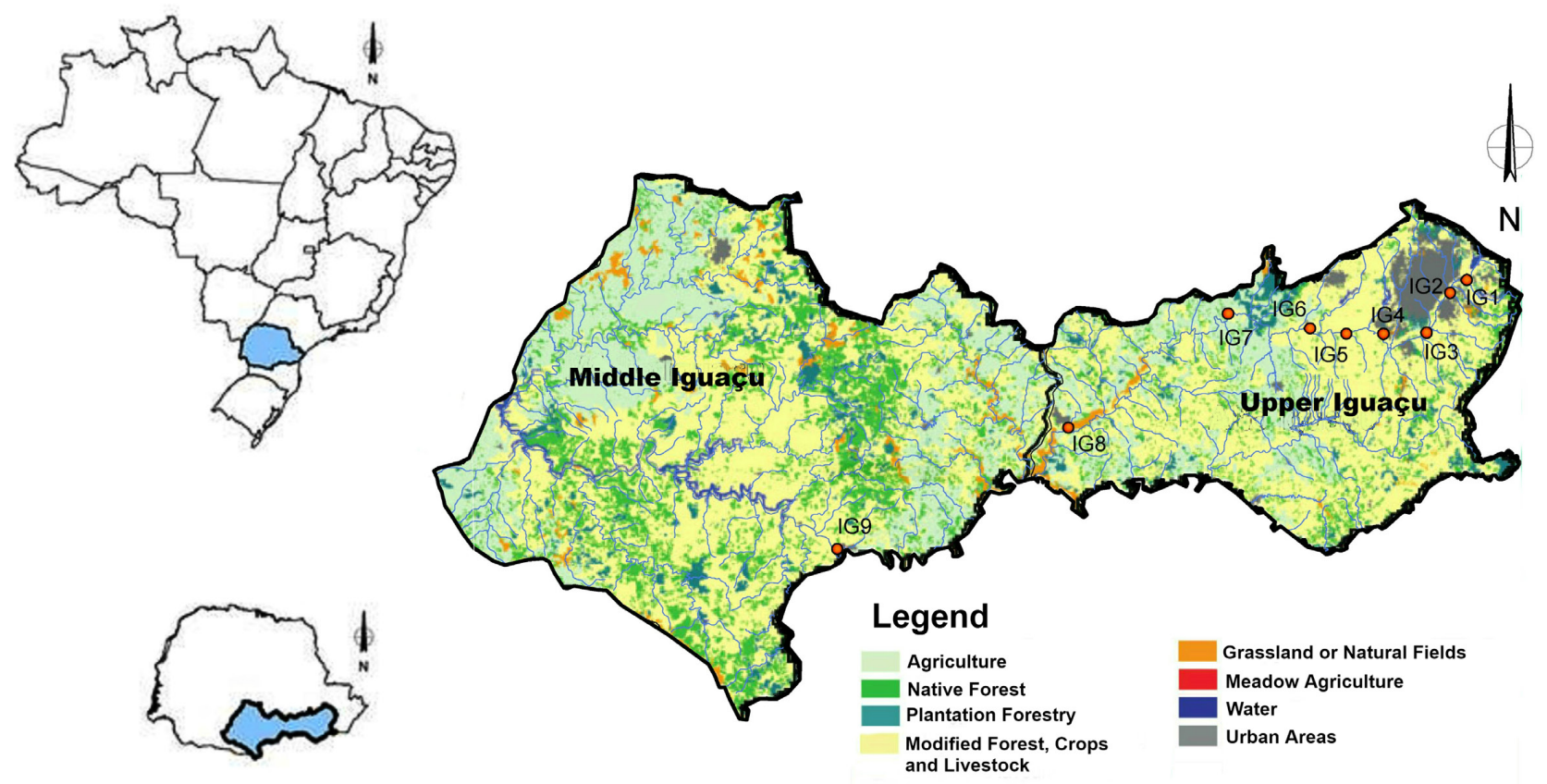

Figure 1. Location of collection points and land use in the Upper and Middle Iguaçu basins. Source: Adapted from IPARDES (2013).

Table1. Location of Collection Points held in the Iguaçu River.

\begin{tabular}{|c|c|c|c|c|c|c|}
\hline \multirow{2}{*}{$\begin{array}{c}\text { POINT } \\
\text { OF COLLECTING }\end{array}$} & \multirow{2}{*}{ RIVER } & \multirow{2}{*}{ CITY } & \multirow{2}{*}{$\begin{array}{l}\text { DRAINAGE } \\
\text { AREA }\left(\mathrm{km}^{2}\right)\end{array}$} & \multicolumn{2}{|c|}{ UTM (m) } & \multirow{2}{*}{$\begin{array}{l}\text { CLASS OF } \\
\text { USE }\end{array}$} \\
\hline & & & & LATITUDE & LONGITUDE & \\
\hline IG1 & Iraí & Piraquara & 282.9 & $7,184,651.350$ & $686,974.225$ & 3 \\
\hline IG2 & & São José dos Pinhais & 625.5 & $7,180,287.792$ & $682,025.920$ & 4 \\
\hline IG3 & & São José dos Pinhais & $1,283.7$ & $7,167,578.838$ & $674,659.448$ & 4 \\
\hline IG4 & & Araucária & $2,122.2$ & $7,167,597.183$ & $660,896.966$ & 4 \\
\hline IG5 & Jom & Araucária & $2,577.8$ & $7,167,732.331$ & $649,296.458$ & 4 \\
\hline IG6 & lguaçu & Balsa Nova & $3,048.7$ & $7,169,311.301$ & $637,420.050$ & 3 \\
\hline IG7 & & Porto Amazonas & $3,662.0$ & $7,173,883.511$ & $611,572.869$ & 3 \\
\hline IG8 & & São Mateus do Sul & $6,050.0$ & $7,137,918.390$ & $561,142.424$ & 2 \\
\hline IG9 & & União da Vitória & $24,500.0$ & $7,099,293.639$ & $487,354.435$ & 2 \\
\hline
\end{tabular}

Source: Adapted from Fernandes (2014); COALIAR (2013) e SUREHMA (1992).

(Method 5310B from Standard Methods) using a Shimadzu ${ }^{\circledR}$ equipment, model TOC-VCPH (APHA, 1999; SHIMADZU, 2003).

UV-Visible spectroscopy was performed with a Varian spectrophotometer, model Cary 50 Conc, and a quartz cuvette with optical path length of $1 \mathrm{~cm}$. The full spectrum was obtained from 200 to $800 \mathrm{~nm}$, with an interval of $0.2 \mathrm{~nm}$ and scan rate of

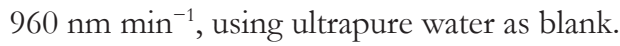

The absorbances obtained in 254 and 285 were used to characterize the organic matter regarding its likely origin in the aquatic ecosystem. The absorptivity specific $254 \mathrm{~nm}$ ultraviolet, $\mathrm{SUVA}_{254}$, was calculated by the ratio of the absorbance of the sample in this wavelength and the your DOC, corrected by the optical path of the cuvette. The higher the value of the SUVA $_{254}$, the greater the aromatic level of the sample, with values close to $4.4 \mathrm{~L}(\mathrm{mg} \mathrm{m})^{-1}$ indicating the predominance of pedogenic $\mathrm{OM}$, and values close to $1.2 \mathrm{~L}(\mathrm{mg} \mathrm{m})^{-1}$ indicating the predominance of aquagenic OM or OM from domestic effluents
(WESTERHOFF; ANNING, 2000). Similarly, the ratio between the absorptivity in $285 \mathrm{~nm}$ and the DOC, $\left(\mathrm{A}_{285} / \mathrm{DOC}\right)$ indicate the OM's predominant molecular structure, with values close to or less than $10 \mathrm{~L} \mathrm{~g}^{-1}$ suggesting the predominance of autochthonous or allochthonous anthropogenic OM, while larger values, in the range of $20 \mathrm{~L} \mathrm{~g}^{-1}$, assume the presence of pedogenic OM (ROSTAN; CELLOT, 1995).

\section{RESULTS AND DISCUSSION}

The water quality of the Iguaçu River was heavily impacted by the presence of high urbanization rates, as observed in the analyzed parameters.

BOD (Figure 2), COD (Figure 3) and DOC data (Figure 4) indicate a worsening in the water quality from the point IG2 $\left(\mathrm{BOD}=11.3 \pm 3.0 \mathrm{mgO}_{2} \mathrm{~L}^{-1} ; \mathrm{COD}=40.4 \pm 17.8 \mathrm{mgO}_{2} \mathrm{~L}^{-1}\right.$; $\mathrm{DOC}=5.4 \pm 0.9 \mathrm{mgC} \mathrm{L}^{-1}$ for the left margin, less degraded) to the 


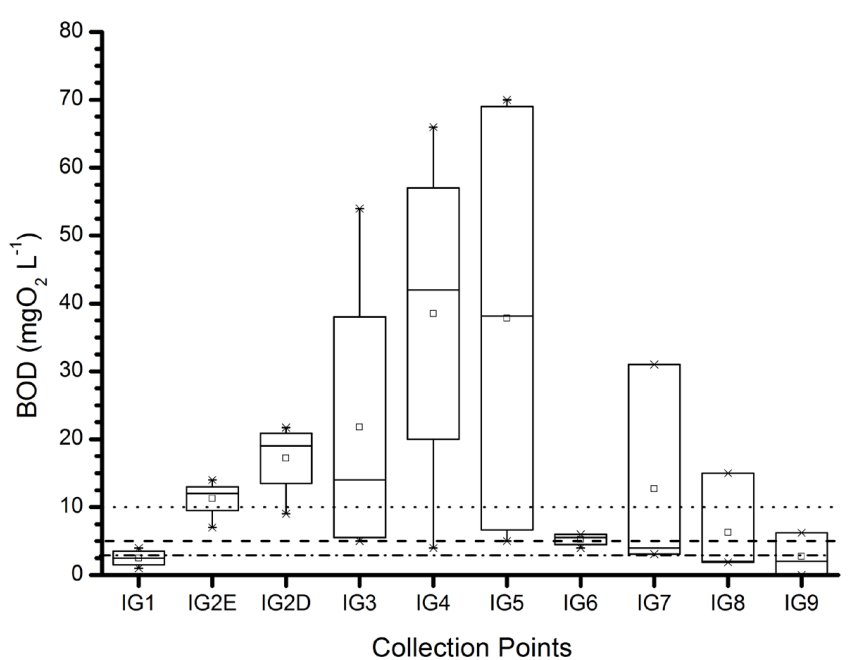

Figure 2. Biochemical Oxygen Demand (dotted line represents the upper limit of class 3, dashed line of class 2 and dot-dash of class 1).

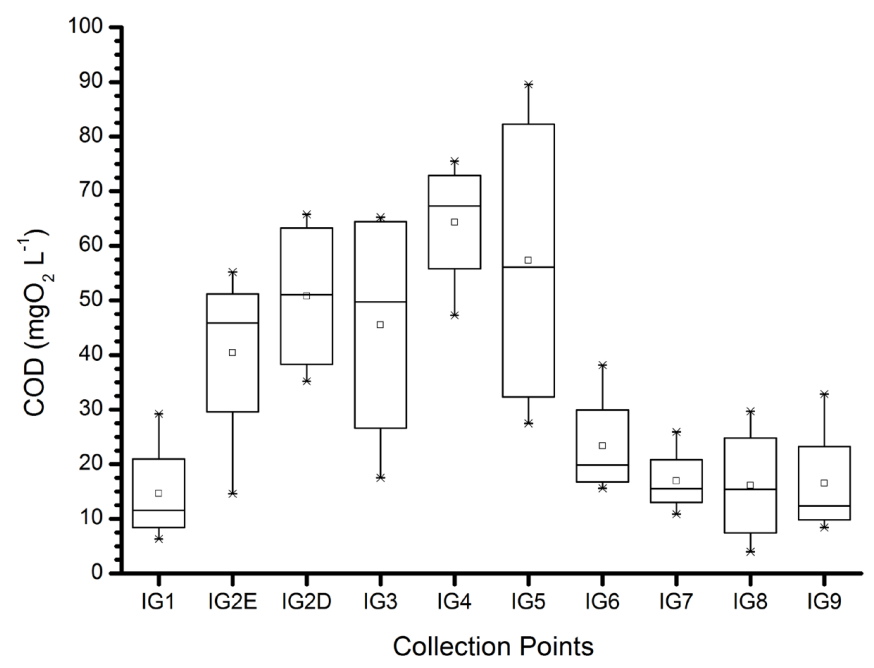

Figure 3. Chemical Oxygen Demand (COD).

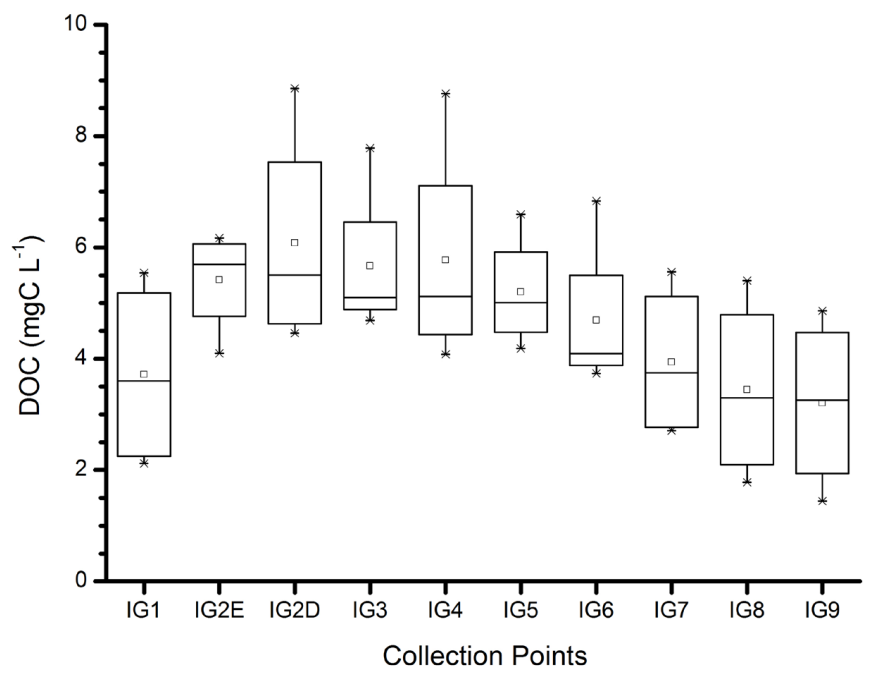

Figure 4. Dissolved Organic Carbon (DOC). point IG5, located just after the most urbanized region of the basin $\left(\mathrm{BOD}=37.8 \pm 36.0 \mathrm{mgO}_{2} \mathrm{~L}^{-1} ; \mathrm{COD}=57.3 \pm 29.7 \mathrm{mgO}_{2} \mathrm{~L}^{-1}\right.$; DOC $=5.2 \pm 1.0 \mathrm{mgC} \mathrm{L}^{-1}$, according to Table 2), due to increased concentration of organic matter, with consequent depletion of the DO (Figure 5) $\left(4.6 \pm 1.0 \mathrm{mgO}_{2} \mathrm{~L}^{-1}\right.$ for IG2E and $1.5 \pm 1.2 \mathrm{mgO}_{2} \mathrm{~L}^{-1}$ for IG5).

From the point IG6 there is a tendency of improvement of the parameters with the reduction of $\mathrm{OM}$ concentration and the recovery of diluted oxygen concentration $\left(B O D=2.7 \pm 3.2 \mathrm{mgO}_{2} \mathrm{~L}^{-1}\right.$; $\mathrm{COD}=16.5 \pm 11.1 \mathrm{mgO}_{2} \mathrm{~L}^{-1} ; \mathrm{DOC}=3.2 \pm 1.6 \mathrm{mgC} \mathrm{L}^{-1}$ and $\mathrm{DO}=6.6 \pm 1.2 \mathrm{mgO}_{2} \mathrm{~L}^{-1}$ for the point IG9, according to Table 2). At this point, small variations in the $\mathrm{BOD}$ values between campaigns are observed, in comparison to other monitoring points. This is probably due to the low urbanization presence in this region, with a flow rate higher than in its upstream area.

Focusing on the classes defined in CONAMA Resolution $357 / 2005$, the DO results obtained in the campaigns show that the point in the Iraí River (IG1) has an average value of DO classified as class 1, changing to class 3 in the left margin of IG2, and class 4 in the right margin of IG2 (Atuba River affluence). In the points IG4 and IG5 the lack of oxygenation is high and the river is out of class, since they present average values of this parameter below $2 \mathrm{mg} \mathrm{L}^{-1}$. In the point IG6 the Iguaçu River IG6 was again classified as class 4 and, for the remaining points to the downstream, the average values ranged between class 1 and class 2 , showing a recovery of the environmental quality of its waters.

On the other hand, evaluating the BOD results, which is the parameter used by COALIAR (Upper Iguaçu Basins and Upper Ribeira Affluents Committee) to classify the watercourses of the Upper Iguaçu basin, the points IG2 to IG5 and IG7 present average values classified as class 4 for this parameter, the points IG6 and IG8 are classified as class 4, and the points IG1 and IG9 are classified as class 1 . That is, at the point of União da Vitória the Iguaçu River presented a quality in relation to the BOD, in average, with values close to those obtained on its spring, in the Iraí River. The averages of the BOD for the points IG2 to IG6 are in the exact classes in which such points were classified.

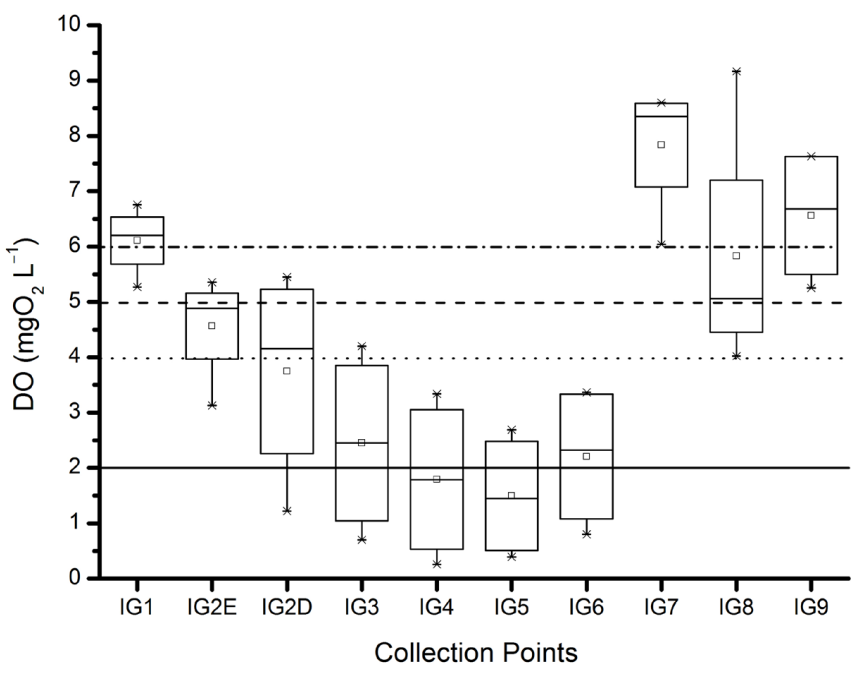

Figure 5. Dissolved Oxygen Concentration (DO) (continuous line represents the lower limit of class 4 , dotted line the limit of class 3 , dashed line the limit of class 2 and dot-dash the limit of class 1). 
Table 2. Results of the analyses in the monitored points.

\begin{tabular}{|c|c|c|c|c|c|c|c|}
\hline POINTS & $\begin{array}{c}\mathrm{DO} \\
\left(\mathrm{mgO}_{2} \mathrm{~L}^{-1}\right)\end{array}$ & $\begin{array}{c}\text { BOD } \\
\left(\mathrm{mgO}_{2} \mathrm{~L}^{-1}\right)\end{array}$ & $\begin{array}{c}\mathrm{COD} \\
\left(\mathrm{mgO}_{2} \mathrm{~L}^{-1}\right)\end{array}$ & $\begin{array}{c}\text { DOC } \\
\left(\mathrm{mgC} \mathrm{L}^{-1}\right)\end{array}$ & $\begin{array}{c}\mathrm{A}_{285} / \mathrm{DOC} \\
\left(\mathrm{L} \mathrm{g}^{-1}\right)\end{array}$ & $\begin{array}{c}\text { SUVA }_{254} \\
\left(\mathrm{~L}(\mathrm{mg} \mathrm{m})^{-1}\right)\end{array}$ & $\begin{array}{c}\text { PREDOMINANT } \\
\text { SOURCE }\end{array}$ \\
\hline IG1 & $6.1 \pm 0.6$ & $2.5 \pm 1.3$ & $14.7 \pm 10.1$ & $3.7 \pm 1.7$ & $32.2 \pm 20.1$ & $4.5 \pm 2.7$ & PEDOGENIC \\
\hline IG2E & $4.6 \pm 1.0$ & $11.3 \pm 3.0$ & $40.4 \pm 17.8$ & $5.4 \pm 0.9$ & $16.1 \pm 4.1$ & $2.4 \pm 0.6$ & MIXED \\
\hline IG2D & $3.7 \pm 1.9$ & $17.2 \pm 5.7$ & $50.8 \pm 14.8$ & $6.1 \pm 2.0$ & $23.0 \pm 10.1$ & $3.0 \pm 1.2$ & MIXED \\
\hline IG3 & $2.5 \pm 1.7$ & $21.8 \pm 22.9$ & $45.5 \pm 23.1$ & $5.7 \pm 1.4$ & $24.1 \pm 8.5$ & $3.3 \pm 1.0$ & MIXED \\
\hline IG4 & $1.8 \pm 1.5$ & $38.5 \pm 26.1$ & $64.3 \pm 12.3$ & $5.8 \pm 2.1$ & $25.0 \pm 13.0$ & $3.4 \pm 1.6$ & MIXED \\
\hline IG5 & $1.5 \pm 1.2$ & $37.8 \pm 36.0$ & $57.3 \pm 29.7$ & $5.2 \pm 1.0$ & $23.6 \pm 8.2$ & $3.3 \pm 1.0$ & MIXED \\
\hline IG6 & $2.2 \pm 1.3$ & $5.3 \pm 1.0$ & $23.4 \pm 10.2$ & $4.7 \pm 1.4$ & $34.5 \pm 19.6$ & $4.5 \pm 2.2$ & PEDOGENIC \\
\hline IG7 & $7.8 \pm 1.2$ & $12.7 \pm 15.9$ & $16.9 \pm 6.4$ & $3.9 \pm 1.4$ & $33.4 \pm 17.3$ & $4.5 \pm 2.2$ & PEDOGENIC \\
\hline IG8 & $5.8 \pm 2.3$ & $6.3 \pm 7.5$ & $16.1 \pm 11.2$ & $3.4 \pm 1.7$ & $31.4 \pm 19.8$ & $4.3 \pm 2.6$ & PEDOGENIC \\
\hline IG9 & $6.6 \pm 1.2$ & $2.7 \pm 3.2$ & $16.5 \pm 11.1$ & $3.2 \pm 1.6$ & $38.4 \pm 14.3$ & $5.1 \pm 1.7$ & PEDOGENIC \\
\hline
\end{tabular}

COD and DOC data follow the same pattern of BOD, with higher values between the points IG2 and IG5. Therefore, not only the biodegradable fraction of organic matter, but also the most refractory, has its concentration reduced to the downstream of the point IG5. The quantitative data used reveal an improvement in the water quality of the Iguaçu River from the point IG6 on, in Balsa Nova, which is a result of the lower urbanization rate of this location and/or of the greater dilution capacity of the river.

Additionally, to evaluate if there was significant changes on the quantitative parameters through the main river, the ANOVA test based on Tukey test and Bartlett and Levene's Method for homogeneity of variance were performed, despite the last one be less sensitive to the hypothesis of normality of the measured data. The COD data base was the water quality parameter series that did not presented homogeneity of variance.

The ANOVA result indicates no significant difference among the monitoring points analyzed, even when considered the DOC data series. It must be emphasized that BOD series presented significant differences for averages ANOVA One-Way, Tukey's Test, Post Hoc probability) between monitoring point IG4 (very polluted) in comparison to IG1 $(p=0.0110)$. IG6 ( $p=0.0197)$. IG7 ( $p=0.0468)$. IG8 $(p=0.0177)$ e IG9 $(p=0.01006)$. IG4 presented significant differences for COD in comparison to IG1 $(p=0.0032)$, IG6 ( $p=0.0192)$, IG7 $(p=0.0515)$, IG8 $(p=0.0043)$ and IG9 $(p=0.0047)$.

In respect to DO, the IG4 and IG5 points presented lower average values and the main differences in relation to the other points. IG4 presented a significant difference in relation to IG1 $(p=0.0401)$, IG7 $(p=0.0007)$ and IG9 $(p=0.0142)$ and IG5 in relation to IG1 $(p=0.0371)$, IG7 $(p=0.0008)$ and IG9 $(p=0.0142)$.

The results of ANOVA from point IG4 in terms of BOD, COD and OD confirm that this point is one of the most degraded. The IG1, IG6, IG7, IG8 and IG9 points are the least degraded in terms of organic matter concentration.

As for the spectroscopic analyzes, it was verified that the river was affected by the intense urbanization of the MRC, both quantitatively and qualitatively. The SUVA values (Figure 6 ) and $\mathrm{A}_{285} / \mathrm{COD}$ (Figure 7 ) variation in the possible sources of organic matter along the studied section. The IG1 point presented high values of these parameters $\left(\mathrm{SUVA}_{254}=4.5 \pm 2.7 \mathrm{~L}(\mathrm{mg} \mathrm{m})^{-1}\right.$ and $\left.\mathrm{A}_{285} / \mathrm{COD}=32.2 \pm 20.1 \mathrm{~L} \mathrm{~g}^{-1}\right)$, indicating the predominance of pedogenic organic matter. However,

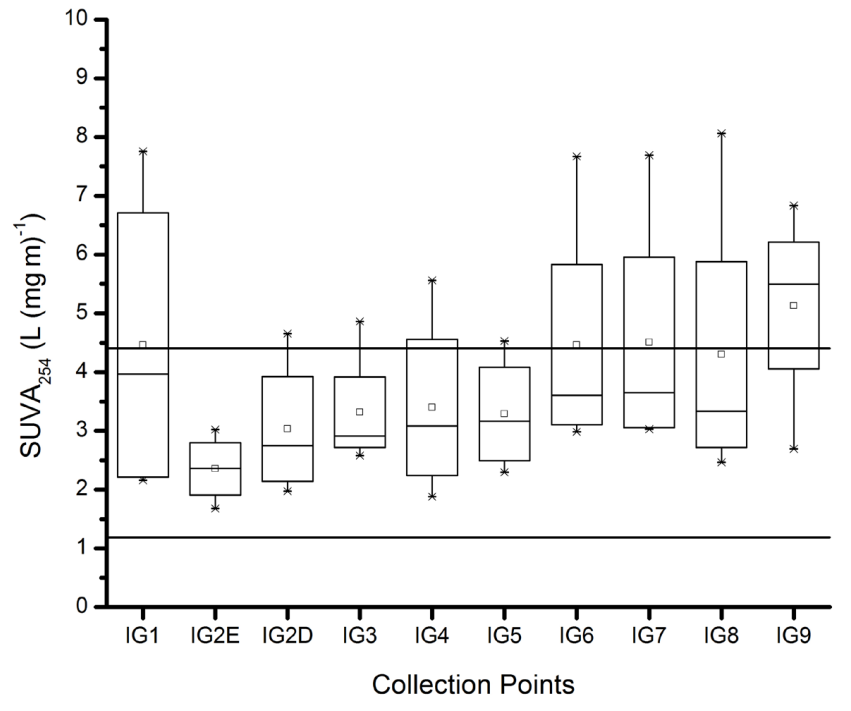

Figure 6. Specific Ultraviolet Absorbance at $254 \mathrm{~nm}$ normalized by DOC.

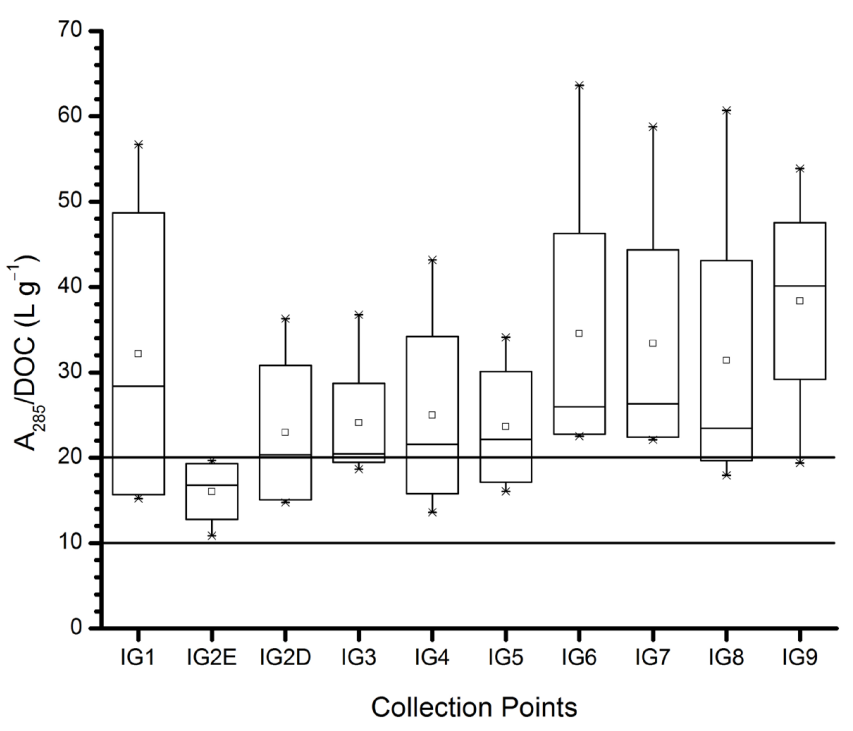

Figure 7. Absorbance at $285 \mathrm{~nm}$ and DOC ratio. 
from the IG2 point the values found for these parameters were lower $\left(\mathrm{SUVA}_{254}=2.4 \pm 0.6 \mathrm{~L}(\mathrm{mg} \mathrm{m})^{-1}\right.$ and $\mathrm{A}_{285} / \mathrm{COD}=16.1 \pm 4.1 \mathrm{~L} \mathrm{~g}^{-1}$ for Left Margin, less polluted), suggesting that from this point there is a greater presence of labile aquagenic organic matter or the contribution of anthropic allochthonous organic matter. Due to the lotic characteristic of the analyzed environment, the labile material was probably derived from domestic effluents. As from the IG6, there is again a higher prevalence of refractory organic matter in relation to the most labile one, with higher values of SUVA $_{254}$ and $\mathrm{A}_{285} /$ DOC $\left(\mathrm{SUVA}_{254}=5.1 \pm 1.7 \mathrm{~L}(\mathrm{mg} \mathrm{m})^{-1}\right.$ and $\mathrm{A}_{285} / \mathrm{COD}=38.4 \pm 14.3 \mathrm{~L} \mathrm{~g}^{-1}$, for IG9, as Table 2).

The spectroscopic data indicated that the improvement in the quality of water downstream of IG5, characterized by a lower concentration of BOD and greater DO, was not only due to the dilution factor of the Iguaçu River as a result of higher flow rate, but also by reason of the lower contribution of organic matter that comes largely from domestic sewage. In addition, it was observed that the high values of such parameters at all points causes Iguaçu River to have a high portion of pedogenic refractory organic matter. This is supported by the fact that spectroscopic parameters, although inferior, still indicate the predominance of aromatic compounds in most points, even the ones strongly impacted by anthropogenic effluents.

The results of this study are in line with those obtained by Bem et al. (2013) and Knapik, Fernandes and Azevedo (2014), in which it was also verified that the MRC has a high impact on the OM, both quantitatively and qualitatively, since there is an increase in OM from the IG2 point, with a reduction in the values of $\mathrm{SUVA}_{254}$ and $\mathrm{A}_{285} / \mathrm{DOC}$. Thus, it was demonstrated that there is contribution of labile OM from this point, indicating the probable disposal of domestic effluents, which may or may not be treated.

However, previous studies only evaluated the $\mathrm{OM}$ in the Iguaçu River as far as the city of Balsa Nova (IG6). At this point, there is evidence of improved water quality. Thus, the present study confirms that the Iguaçu River presents a recovery of its quality through the analysis of three more points downstream (IG7 to IG9), and that this improvement in water quality is due to both the lower effluent input and the greater capacity of dilution of the river in this section.

These results are important for the management of water resources, since the understanding of the composition of organic matter and its probable sources (natural, domestic effluents or diffuse pollution), as well as their quantification, is fundamental in choosing the technologies or actions necessary for depolluting bodies of water.

\section{CONCLUSION}

The analyzed data indicated that the MRC causes strong pressure, from the dynamics of the Organic Matter, on the Iguaçu River in the section with strong anthropic action. This region induces high degradation of the quality of its waters, having stretches with the DO close to zero, with potential of causing serious consequences for biome and natural processes. However, the river shows good recovery after the city of Balsa Nova up to União da
Vitória, a region with more rural characteristics, with the presence of agriculture, livestock and forest remnants.

The integration between the quantitative and qualitative data used was fundamental for a better understanding of the sources of organic matter along the course of the Iguaçu River, indicating the predominance of refractory fractions near the source and in the less urbanized regions, and an increase in the most labile fractions in the MRC. Thus, the use of UV-Visible spectroscopy data was important for the assessment of pollutant sources, which has a great impact on the management of water resources, especially in relation to the decision-making in pollution action.

As seen, the analytical techniques usually employed in characterization of $\mathrm{OM}$ present weaknesses in relation to your determination, as the high dependence of the bacterial community and the high time spent on BOD, or the possible interference in the analysis of DOC and COD (with direct impact of the latter on the determination of contents $\mathrm{SUVA}_{254}$ and $\mathrm{A}_{285}$ /COD). Therefore, using both, as performed in the present study, allowed for a more reliable evaluation of the data obtained, including the determination of the predominant sources of OM.

In this context, it is worth noting that the qualitative and quantitative approach presented here for understanding of water bodies degradation processes is an opportunity for water resources management of potentially establishing new classification criteria that can change the understanding water resources management tools, not yet studied in depth nor referenced in current legislation.

Thus, the proposal of new water quality indicators related to the inclusion of spectroscopic and DOC data in environmental legislation should be the focus of future studies, especially in cases of contamination of water bodies that require emergency actions, in which the analysis of BOD is inadequate due to the long time required for analysis.

\section{ACKNOWLEDGEMENTS}

The authors express the relevance of CAPES and CNPq considering the financial support for the development of this research. We want to thank the positive questions and insights from the anonymous reviewers who made this manuscript more consistent

\section{REFERENCES}

AIKEN, G.; COTSARIS, E. Soil and hydrology: their effect on nom. Journal AWWA - American Water Works Association, v. 87, n. 1, p. 36-45, 1995.

ANA - AGÊNCIA NACIONAL DE ÁGUAS; MMA MINISTÉRIO DO MEIO AMBIENTE. Conjuntura dos recursos bídricos no Brasil: regiões hidrográficas brasileiras. Brasília: ANA, 2015. Edição Especial.

APHA - AMERICAN PUBLIC HEALTH ASSOCIATION; AWWA - AMERICAN WATER WORKS ASSOCIATION; WEF - WATER ENVIRONMENT FEDERATION. Standard methods for the examination of water and wastewater. 20. ed. Canada: APHA; AWWA; WEF, 1999. 
BEM, C. C.; KNAPIK, H. G.; FERNANDES, C. V. S.; BRAGA, M. C. B.; AZEVEDO, J. C. R. Características da matéria orgânica estudo comparativo de padrões de espectrometria de fluorescência e UV-Vis de rio e lago em bacias urbanizadas. Revista Brasileira de Recursos Hídricos, v. 18, n. 1, p. 135-147, 2013. http://dx.doi. org/10.21168/rbrh.v18n1.p135-147.

CERH-PR - CONSELHO ESTADUAL DE RECURSOS HÍDRICOS DO PARANÁ. Resolução n. 49, de 20 de dezembro de 2006. Dispõe sobre a instituição de Regiões Hidrográficas, Bacias Hidrográficas e Unidades Hidrográficas de Gerenciamento de Recursos Hídricos do Estado do Paraná. Diário Oficial [da] Estado, Curitiba, 31 jan. 2007.

CHEN, J.; GU, B.; LEBOEUF, E. J.; PAN, H.; DAI, S. Spectroscopic characterization of the structural and functional properties of natural organic matter fractions. Chemosphere, v. 48, n. 1, p. 5968, 2002. PMid:12137058. http://dx.doi.org/10.1016/S00456535(02)00041-3.

COALIAR - COMITÊ DAS BACIAS DO ALTO IGUAÇU E AFLUENTES DO ALTO RIBEIRA. Resolução n. 04, de 11 de julho de 2013. Aprova proposição de atualização do enquadramento dos corpos de água superficiais de domínio do Estado do Paraná, na área de abrangência do Comitê das Bacias do Alto Iguaçu e Afluentes do Alto Ribeira, em classes, de acordo com os usos preponderantes. Aguas Paraná: Instituto das Águas do Paraná, Curitiba, 11 jul. 2013.

COMBER, N. D. W.; GARDNER, M. J.; GUNN, A. M. Measurement of absorbance and fluorescence the potential alternatives to BOD. Environmental Technology, v. 17, n. 7, p. 771-776, 1996. http://dx.doi. org/10.1080/09593331708616444.

CONAMA - CONSELHO NACIONAL DO MEIO AMBIENTE. Resolução n. 357, de 17 de março de 2005. Dispõe sobre a classificação dos corpos de água e diretrizes ambientais para o seu enquadramento, bem como estabelece as condições e padrões de lançamento de efluentes, e dá outras providências. Diário Oficial [da] República Federativa do Brasil, Brasília, 18 mar. 2005.

DANG, D. H.; LENOBLE, V.; DURRIEU, G.; MULLOT, J.-U.; MOUNIER, S.; GARNIER, C. Sedimentary dynamics of coastal organic matter: an assessment of the porewater size/reactivity model by spectroscopic techniques. Estuarine, Coastal and Shelf Science, v. 151, p. 100-111, 2014. http://dx.doi.org/10.1016/j. ecss.2014.10.002.

DONG, Q.; LI, P.; HUANG, Q.; ABDELHAFEZ, A. A.; CHEN, L. Occurrence, polarity and bioavailability of dissolved organic matter in the Huangpu River, China. Journal of Environmental Sciences, v. 26, n. 9, p. 1843-1850, 2014. PMid:25193833. http:// dx.doi.org/10.1016/j.jes.2014.06.020.

ESTEVES, F. D. A. Fundamentos de limnologia. 2. ed. Rio de Janeiro: Interciência, 1998.
FERNANDES, C. V. S. (Coord.). INTEGRA 2: bases técnicas para a integração de instrumentos de gestão de recursos hídricos. Curitiba: UFPR, 2014. Relatório Parcial no 1.

FILELLA, M. Freshwaters: which NOM matters? Environmental Chemistry Letters, v. 7, n. 1, p. 21-35, 2009. http:/ /dx.doi.org/10.1007/ s10311-008-0158-x.

FRIMMEL, F. H. Characterization of natural organic matter as major constituents in aquatic systems. Journal of Contaminant Hydrology, v. 35, n. 1-3, p. 201-216, 1998. http://dx.doi.org/10.1016/ S0169-7722(98)00133-8.

HESTIR, E. L.; BRANDO, V.; CAMPBELL, G.; DEKKER, A.; MALTHUS, T. The relationship between dissolved organic matter absorption and dissolved organic carbon in reservoirs along a temperate to tropical gradient. Remote Sensing of Environment, v. 156, p. 395-402, 2015. http://dx.doi.org/10.1016/j.rse.2014.09.022.

HU, Z.; GRASSO, D. Water analysis: chemical oxygen demand. In: WORSFOLD, P.; TOWNSHEND, A.; POOLE C. (Eds.). Encyclopedia of analytical science. 2. ed. Amsterdam: Elsevier Academic Press, 2005. p. 325-330.

HUR, J.; KONG, D. S. Use of synchronous fluorescence spectra to estimate Biochemical Oxygen Demand (BOD) of urban rivers affected by treated sewage. Environmental Technology, v. 29, n. 4, p. 435-444, 2008. PMid:18619148. http://dx.doi. org/10.1080/09593330801984472.

IPARDES-INSTITUTOPARANAENSEDEDESENVOLVIMENTO ECONÔMICO E SOCIAL. Indicadores de desenvolvimento sustentável por bacias hidrográficas do Estado do Paraná. Curitiba: IPARDES, 2013. 245 p.

JOUANNEAU, S.; RECOULES, L.; DURAND, M. J.; BOUKABACHE, A.; PICOT, V.; PRIMAULT, Y.; LAKEL, A.; SENGELIN, M.; BARILLON, B.; THOUAND, G. Methods for assessing biochemical oxygen demand (BOD): a review. Water Research, v. 49, n. 1, p. 62-82, 2014. PMid:24316182. http://dx.doi. org/10.1016/j.watres.2013.10.066.

KNAPIK, H. G. Organic matter characterization and modeling in polluted rivers for water quality planning and management. 2014. 281 f. Tese (Doutorado em Engenharia de Recursos Hídricos e Ambiental) Departamento de Hidráulica e Saneamento, Universidade Federal do Paraná, Curitiba, 2014.

KNAPIK, H. G.; FERNANDES, C. V. S.; AZEVEDO, J. C. R. Aplicabilidade de técnicas de espectroscopia e da concentração de carbono orgânico dissolvido na caracterização da matéria orgânica em rios urbanos. Revista Brasileira de Recursos Hídricos, v. 19, n. 4, p. 214-225, 2014. http://dx.doi.org/10.21168/rbrh.v19n4.p214-225.

KUMAR, R.; KUMAR, A. Water analysis: biochemical oxygen demand. In: WORSFOLD, P.; TOWNSHEND, A.; POOLE, C.; (Eds.). Encyclopedia of analytical science. 2nd. ed. Amsterdam: Elsevier Academic Press, 2005. p. 315-325. 
LEENHEER, J. A.; CROUÉ, J.-P. Peer reviewed: characterizing aquatic dissolved organic matter - understanding the unknown structures is key to better treatment of drinking water. Environmental Science \& Technology, v. 37, n. 1, p. 18A-26A, 2003. PMid:12542280. http://dx.doi.org/10.1021/es032333c.

LOPARDO, A. T. V.; FERNANDES, C. V. S.; AZEVEDO, J. C. R. Caracterização do carbono orgânico para avaliação ambiental da qualidade da água: estudo de caso do Lago do Parque Barigüi. Revista Brasileira de Recursos Hídricos, v. 13, n. 3, p. 23-34, 2008.

MENG, F.; HUANG, G.; YANG, X.; LI, Z.; LI, J.; CAO, J.; WANG, Z.; SUN, L. Identifying the sources and fate of anthropogenically impacted dissolved organic matter (DOM) in urbanized rivers. Water Research, v. 47, n. 14, p. 5027-5039, 2013. PMid:23863376. http://dx.doi.org/10.1016/j.watres.2013.05.043.

NGUYEN, H. V.-M.; HUR, J. Tracing the sources of refractory dissolved organic matter in a large artificial lake using multiple analytical tools. Chemosphere, v. 85, n. 5, p. 782-789, 2011. PMid:21752424. http://dx.doi.org/10.1016/j.chemosphere.2011.06.068.

PAVIA, D. L.; LAMPMAN, G. M.; KRIZ, G. S.; VYVYAN, J. R. Introducão à espectroscopia. 4. ed. São Paulo: Cengage Learning, 2012. Tradução.

POUET, M.-F.; THERAULAZ, F. MESNAGE, V.; THOMAS, O. Natural water. In. THOMAS, O.; BURGESS, C. (Eds.). UV-visible spectrophotometry of water and wastewater: techniques and instrumentation in analytical chemistry. v. 27. Amsterdam: Elsevier, 2007. cap. 7, p. 163-188.

ROSTAN, J. C.; CELLOT, B. On the use of UV spectrophotometry to assess dissolved organic carbon origin variations in the Upper Rhone River. Aquatic Sciences, v. 57, n. 1, p. 70-80, 1995. http:// dx.doi.org/10.1007/BF00878027.

SANTOS, M. M.; IDE, A. H.; KRAMER, R. D.; MIZUKAWA, A.; VAN KAICK, T. S.; AZEVEDO, J. C. R. Avaliação da contaminação de corpos hídricos da bacia do Alto Iguaçu através de matrizes de excitação-emissão de fluorescência. In: XIV WORLD WATER CONGRESS, 14., 2011, Porto de Galinhas. Anais..., 2011.

SEMA - SECRETARIA DE ESTADO DE MEIO AMBIENTE. Bacias hidrográficas do Paraná. Curitiba: SEMA, 2013. Série Histórica.

SHIMADZU. TOC-VCPH/CPN \& TOC-Control V software: user manual. Kyoto: Shimadzu Corporation, 2003. 416 p.

SKOOG, D. A.; WEST, D. M.; HOLLER, F. J.; CROUCH, S. R. Fundamentos de química analítica. 8. ed. São Paulo: Thomson, 2006. Tradução.

SUREHMA - SUPERINTENDÊNCIA DOS RECURSOS HÍDRICOS E MEIO AMBIENTE. Portaria n. 20, de 12 de maio de 1992. Diário Oficial [do] Estado, Curitiba, 28 mai. 1992.
VINADÉ, M. E. C.; VINADÉ, E. R. C. Métodos espectroscópicos de análise quantitativa. Santa Maria: UFSM, 2005.

VISCO, G.; CAMPANELLA, L.; NOBILI, V. Organic carbons and TOC in waters: an overview of the international norm for its measurements. Microchemical Journal, v. 79, n. 1-2, p. 185-191, 2005. http://dx.doi.org/10.1016/j.microc.2004.10.018.

WEISHAAR, J. L.; AIKEN, G. R.; BERGAMASCHI, B. A.; FRAM, M. S.; FUJII, R.; MOPPER, K. Evaluation of specific ultraviolet absorbance as an indicator of the chemical composition and reactivity of dissolved organic carbon. Environmental Science \& Technology, v. 37, n. 20, p. 4702-4708, 2003. PMid:14594381. http://dx.doi.org/10.1021/es030360x.

WESTERHOFF, P.; ANNING, D. Concentrations and characteristics of organic carbon in surface water in Arizona: Influence of urbanization. Journal of Hydrology, v. 236, n. 3-4, p. 202-222, 2000. http://dx.doi.org/10.1016/S0022-1694(00)00292-4.

WILKINSON, K. J.; JOZ-ROLAND, A.; BUFFLE, J. Different roles of pedogenic fulvic acids and aquagenic biopolymers on colloid aggregation and stability in freshwaters. Limnology and Oceanography, v. 42, n. 8, p. 1714-1724, 1997. http://dx.doi. org/10.4319/lo.1997.42.8.1714.

YAMASHITA, Y.; MCCALLISTER, S. L.; KOCH, B. P.; GONSIOR, M.; JAFFÉ, R. Dynamics of dissolved organic matter in fjord ecosystems: Contributions of terrestrial dissolved organic matter in the deep layer. Estuarine, Coastal and Shelf Science, v. 159, p. 37-49, 2015. http://dx.doi.org/10.1016/j.ecss.2015.03.024.

YU, H.; SONG, Y.; GAO, H.; LIU, L.; YAO, L.; PENG, J. Applying fluorescence spectroscopy and multivariable analysis to characterize structural composition of dissolved organic matter and its correlation with water quality in an urban river. Environmental Earth Sciences, v. 73, n. 9, p. 5163-5171, 2015. http:// dx.doi.org/10.1007/s12665-015-4269-y.

ZUMSTEIN, J.; BUFFLE, J. Circulation of pedogenic and aquagenic organic matter in an eutrophic lake. Water Research, v. 23, n. 2, p. 229-239, 1989. http://dx.doi.org/10.1016/0043-1354(89)90047-X.

\section{Authors contributions}

Juliana Leithold: Article writing, data analysis and interpretation, general design, final review.

Cristóvão Vicente Scapulatempo Fernandes: Guidance, general design, proofreading, final review of translated article.

Heloise Garcia Knapik: Guidance, general design, proofreading, final revision.

Júlio César Rodrigues de Azevedo: Guidance, general design, proofreading, final revision. 